\title{
STRATEGI DAN EFISIENSI PERSEDIAAN BAHAN BAKU DI PT.XYZ
}

\author{
STRATEGY AND RAW MATERIAL INVENTORY EFFICIENCY IN PT. XYZ
}

\author{
Dody Alexander Nababan ${ }^{* 1}$, Machfud ${ }^{* *)}$, dan Arief Safari***) \\ *) Sekolah Bisnis, IPB University \\ Jl. Raya Pajajaran, Bogor 16151 \\ ${ }^{* *}$ Departemen Teknologi Industri Pertanian, Fakultas Teknologi Pertanian, IPB University \\ Kampus IPB Darmaga PO BOX 220, Bogor 16002 \\ ***) Institut Teknologi dan Bisnis Ahmad Dahlan \\ Jl. Ciputat Raya No. 77 Cireundeu, Ciputat 15419
}

\begin{abstract}
Raw material control is a critical factor in a company to fulfill the production requirement and cost. This research aims to identify company function in keeping the relationship among suppliers and also to formulate efficient raw material management. The company cooperates with several suppliers as "partners" that integrated and classified on raw material procurement. The classification of raw materials in 2016 and 2017 using the ABC method showed that the raw materials categorize as class $A$ (have a large useful value). The forecasting error of raw materials was compared with quadratic, linear, moving average, and double exponential smoothing methods. There were four types of raw materials that have a smaller forecast than a company method for the year 2016 and one type for raw material in 2017. There was one material that has an optimal $Q$ negative because of its negative function. The total costs incurred were mostly lower if using company methods, and so it could be concluded that the company fulfilled the efficiency level. The buffer stock calculation could be used as a guide for companies to handle weekly raw material requirements in order to avoid out of stock.
\end{abstract}

Keywords: $A B C$, Forecasting, EOQ, Inventory, raw material

\begin{abstract}
Abstrak: Pengendalian bahan baku merupakan hal yang sangat penting dalam sebuah perusahaan agar dapat memenuhi kebutuhan produksi maupun biaya yang dikeluarkan. Penelitian ini bertujuan mengidentifikasi fungsional perusahaan dalam menjaga hubungan dengan pemasok dan merumuskan kebijakan pengelolaan bahan baku yang efisien bagi perusahaan. Perusahaan melakukan kerjasama dengan beberapa pemasok dengan tipe partnership yang sudah terintegrasi untuk pengadaan bahan bakunya. Pengklasifikasian bahan baku tahun 2016 dan 2017 dengan metode $\mathrm{ABC}$ menunjukkan beberapa bahan baku yang masuk kedalam kelas A yang memiliki nilai pemakaian yang besar. Kesalahan peramalan bahan baku tersebut dibandingkan dengan metode kuadratik, linear, moving average dan double exponential smoothing. Terdapat empat jenis bahan baku yang memiliki nilai peramalan lebih kecil dengan metode perusahaan untuk tahun 2016 dan satu jenis untuk bahan baku tahun 2017. Hanya satu bahan baku yang memiliki Q optimum negatif karena fungsinya negatif. Total biaya yang dikeluarkan sebagian besar masih lebih rendah dengan menggunakan metode perusahaan. Sehingga dapat dikatakan metode perusahaan masih memenuhi tingkat efisiensi. Perhitungan persediaan pengaman yang dihasilkan dapat menjadi acuan perusahaan untuk menjaga permintaan per minggu agar tidak terjadi kehabisan bahan baku.
\end{abstract}

Kata kunci: $\mathrm{ABC}$, peramalan, EOQ, sediaan, bahan baku

\footnotetext{
${ }^{1}$ Corresponding author:

Email: nababanalexanderdody@gmail.com
} 


\section{PENDAHULUAN}

Perusahaan merupakan sebuah organisasi yang berfokus pada pencapaian keuntungan untuk kelangsungan perusahaan tersebut. Hal tersebut dapat tercapai jika perusahaan mempunyai perencanaan yang baik dalam setiap kegiatannya. Kegiatan dalam sebuah perusahaan sangat didukung oleh persediaan yang dapat mempengaruhi keuntungan yang akan diperoleh. Strategi fungsional dalam pengadaan bahan baku menjadi strategi yang penting dalam meningkatkan efektivitas dan efisiensi pengadaan. Kegiatan dalam sebuah perusahaan sangat didukung oleh persediaan yang dapat mempengaruhi keuntungan yang akan diperoleh. Persediaan ini diperoleh dari pemasok yang ditunjuk perusahaan berdasarkan kriteria yang diinginkan perusahaan. Sehigga hubungan baik dengan pemasok menjadi sangat penting agar bahan baku yang diinginkan perusahaan tetap ada.

PT XYZ yang merupakan perusahaan pengolahan kayu memiliki kriteria tersendiri dalam pemenuhan bahan baku. Bahan baku yang digunakan perusahaan juga terdiri dari berbagai jenis serta penggunaan yang berbeda pula. Secara umum Verma dan Pullman (1998) menggunakan lima kriteria pemasok yang harus diperhatikan yakni biaya komponen bahan baku, kualitas komponen bahan baku, jangka waktu pengiriman, ketepatan waktu pengiriman, dan fleksibilitas dalam penggantian pesanan. Evaluasi juga dapat dilakukan jika pemasok tidak dapat memenuhi pesanan seprti menurut Sarkar (2006), pengurangan pemasok merupakan proses keputusan strategis yang melibatkan retensi dari sejumlah pemasok yang terbatas untuk mengembangkan hubungan jangka panjang dengan pemasok. Pemenuhan persediaan berawal dari peramalan bahan baku. Hal ini berkaitan terhadapjumlah yang akan dipesan untuk periode berikutnya. Karenajika peramalan tidak tepat, maka akan dapat memberikan dampak yang kurang baik. Jika peramalan berlebih dari penggunaan maka akan ada biaya tambahan dari bahan baku yang berlebih. Sebaliknya, jika peramalan lebih rendah dari penggunaan nyata maka proses produksi akan terganggu karena kekurangan bahan baku.

Meskipun demikian, dalam beberapa pemahaman, persediaan dianggap sebagai sesuatu yang tidak perlu karena hanya menimbulkan biaya tambahan. Rajeev (2008) bahkan mengatakan akibat ketidaktepatan biaya dalam sediaan dapat mengakibatkan hilangnya produktifitas, potensi keuntungan dari ketidakmampuan memenuhi permintaan pelanggan, serta keuangan dan kompetitif perusahaan. Hasil penelitian Prihatna (2007) mengatakan strategi peningkatan rantai pasok PT. Fajar Taurus memiliki empat faktor, yakni inventori yang rendah, mutu terjamin, dan penyediaan barang lancar. Maka langkah strategis yang diambil perusahaan dalam hubungannya dengan pemasok yakni standarisasi hari dari pemasok, reformasi kontrak kerja, dan alternatif pola kemitraan. Menjalin komunikasi dan kolaborasi dengan para pemasok dapat menjadi strategi purchasing (Tarigan, 2009). Analisa SWOT dapat dilakukan untuk dapat melihat strategi yang dapat dilakukan perusahaan. Salah satunya Strategi jangka panjang untuk melakukan diversifikasi produk dan efisiensi bahan baku. Sedangkan jangka pendek dapat melakukan peningkatan penjualan terutama mencari konsumen baru dengan efisiensi bahan baku, konsistensi mutu produk dan menjaga hubungan baik dengan konsumen lama (Ananta et al. 2007).

Tingkatan persediaan dan kontinuitas bahan baku tidak terlepas dari peramalan yang dilakukan perusahaan. Semakin tepat peramalan maka biaya yang dikeuarkan perusahaan semakin efisien. Tingkat kesalahan antar metode penting untuk diketahui seperti yang dilakukan Widiyarini (2016) dihasilkan metode double exponential smoothing lebih baik dari moving average dilihat dari nilai MAPE terkecil. Hayuningtyas (2017) juga melakukan penelitian peramalan persediaan dengan metode weighted moving average lebih baik dari double exponential smoothing dengan melihat nilai MSE terkecil. Utama (2016) juga melakukan peramalan persediaan agar optimal dengan melihat MAD yang terkecil dengan double exponential smoothing.

Penggunaan bahan baku yang fluktuatif juga mempengaruhi dalam peramaan kebutuhan dan biaya yang dikeluarkan. Windria (2001) memperhatikan persediaan ikan Tuna Loid menggunakan metode probabilistik dengan memperhatikan perubahan tingkat penjualan dan kebutuhan bahan baku selama lead time dan kemungkinan kehabisan bahan baku (stock out). Jumlah pemesanan bahan baku yang optimal dan jumlah penyangga (buffer stock) ikan Tuna Loid lebih efisien sebesar Rp24.771.072 dan 21.053,14 kg dibandingkan dengan metode perusahaan.

Penelitian ini bertujuan menganalisis strategi fungsional perusahaan berdasarkan situasi perusahaan dan merumuskan kebijakan pengelolaan bahan baku yang efisien bagi PT XYZ serta memberikan solusi dalam pengendalian bahan baku. 


\section{METODE PENELITIAN}

Penelitian ini dilakukan di PT XYZ yang berlokasi di Gunung Puteri, Bogor. Pengumpulan dan pengolahan data dilakukan pada bulan September 2017. Data yang digunakan pada penelitian ini terdiri atas data kualitatif dan kuantitatif baik data primer maupun sekunder. Data primer didapatkan melalui wawancara dan observasi kepada menejer umum, produksi dan operasi. Data sekunder diperoleh dari hasil laporan perusahaan, pengolahan data dan data penggunaan bulanan bahan baku tahun 2016 periode Januar-Desember dan tahun 2017 peridoe Januari-Agustus yang berkaitan dengan penelitian.

Ketidakpastian permintaan, kapasitas produksi, industri terkait, dan sumber daya yang semakin sedikit membuat perusahaan harus berpikir untuk dapat memenuhi permintaan pasar dan tantangan yang ada. Strategi yang tepat perlu dijalankan perusahaan untuk dapat mencapai hal tersebut. Analisis situasi perusahaan dengan SWOT digunakan untuk melihat strategi fungsional yang digunakan perusahaan. Dalam hal ini strategi fungsional perusahaan dalam pengadaan bahan baku. Menjaga hubungan dengan pemasok menjadi penting karena sangat berhubungan dengan jalannya proses produksi. Hal ini dapat diketahui dengan analisa terhadap manajemen pemasok dapat diketahui dengan wawancara secara langsung dengan pihak yang berkaitan baik manajer pemesanan serta observasi langsung. Analisis ini membutuhkan data pemasok dan tipe kerjasama yang dijalankan. Dengan demikian, kita dapat mengetahui secara umum bagaimana perusahaan dapat menjaga hubungan dengan pemasok dalam pemenuhan bahan baku. Data yang kita dapatkan kemudian kita melihat mengenai faktor-faktor penting pemasok, jumlah pemasok, dan tipe hubungan yang digunakan perusahaan dalam mengelola hubungan dengan pemasok secara deskriptif. Selain itu kita juga mendapatkan jenis serta jumlah bahan baku yang selama ini digunakan oleh perusahaan.

Selanjutnya, data jenis dan jumlah bahan baku diklasifikasikan dengan menggunakan metode $\mathrm{ABC}$ untuk mengetahui bahan baku yang masuk ke dalam kategori A. Bahan baku yang masuk ke dalam kategori A kemudian dianalisa tingkat efisiensinya. Diawali dengan melakukan analisis terhadap peramalan yang dilakukan perusahaan dibandingkan dengan metode linier, kuadratik, moving average, dan double exponensial smoothing menggunakan alat Minitab 14. Metode dengan hasil terbaik digunakan untuk peramalan tahun berikutnya dan untuk proyeksi 2018 dihitung jumlah optimumnya. Selanjutnya, data perusahaan dihitung total biaya dalam satu periode untuk mengetahui tingkat efisiensi. Dengan metode EOQ kemudian dibandingkan dengan metode perusahaan. Menghitung stok pengaman yang terbaik untuk menjaga tidak terjadinya kehabisan bahan baku. Berdasarkan hasil analisis manajemen pemasok dan efisiensi bahan baku, dilihat hubungan antara pengadaan bahan baku dengan efisiensi yang didapat. Tahapan penelitian dapat dilihat pada Gambar 1.

\section{HASIL}

\section{Analisis SWOT}

Strategi yang dapat digunakan perusahaan yang dihasilkan dari SWOT (Gambar 2), yakni meningkatkan efektivitas dan efisiensi manajemen persediaan. Strategi ini merupakan strategi yang dapat dilaksanakan perusahaan dalam menghadapi ancaman dan kekurangan yang dihadapi. Peningkatan efektivitas dan efisiensi manajemen persediaan dapat dilaksanakan dengan strategi fungsional perusahaan. Strategi fungsional ini lebih bersifat operasional karena akan akan langsung diterapkan oleh bagianbagian manajemen yang ada. Bagian pengadaan pada perusahaan merupakan bagian yang melaksanakan strategi fungsional tersebut. Strategi fungsional perusahaan harus dapat meningkatkan efektivitas dan efisiensi dalam pengadaan bahan baku. Meningkatnya efektivitas dan efisiensi dalam pengadaaan bahan baku dapat meningkatkan keuntungan perusahaan.

\section{Manjemen Pemasok}

Perusahaan XYZ memiliki beberapa pemasok yang bekerja sama dalam pemenuhan bahan baku. Terdapat 106 pemasok yang merupakan pemasok bahan baku ke perusahaan XYZ. Pemasok yang dipilih perusahaan merupakan pemasok yang dapat memenuhi kebutuhan perusahaan yakni ketersediaan bahan baku, harga yang lebih murah dan waktu pengiriman. Selain pertimbangan itu, keterlibatan kolaborasi antara pengetahuan pekerja dengan keahlian yang berbeda dapat menjadikan pemilihan pemasok lebih relevan menjadi strategi perusahaan (Ordoobadi, 2011). Ada beberapa yang menjadi pertimbangan perusahaan yakni harga, waktu tunggu, tempo pembayaran, kualitas, 
dan legalitas perusahaan. Selain itu manajemen rantai pasok menurut Thomas dan Griffin (1996), merupakan pengelolaan arus material dan informasi baik dalam perusahaan maupun antara vendor, manufaktur maupun pabrik perakitan dan juga pusat distribusi.

Berdasarkan teori yang disampaikan Wheelen et al. (2012), ada tiga strategi yang dapat dipakai dalam pemenuha bahan baku, yakni multiple, sole, dan parallel sourcing. Jika melihat yang dilakukan oleh perusahaan saat ini maka strategi yang dilakukan perusahaan masuk ke dalam tipe multiple. Dimana perusahaan melakukan kerjasama dengan beberapa pemasok (minimal dua pemasok) untuk pemenuhan bahan baku. Terlihat dari data bahan baku yang dipesan untuk satu jenis dapat berasal lebih dari satu pemasok. Hubungan antar pemasok dan perusahaan selama ini termasuk dalam partnership dimana kedua belah pihak lebih terintegrasi satu sama lain (Stock dan Lambert, 2001). Partnership juga memiliki tiga tipe dan dari ketiga tipe tersebut hubungan ini masuk ke tipe I dimana kedua organisasi melakukan koordinasi terbatas dalam kegiatan dan perencanaan. Hanya untuk jangka pendek, dimana perusahaan melakukan pemilihan pemasok dua bulan sekali. Oleh sebab itu, supplier relationship management sangat penting karena memiliki dampak positif terhadap efektivitas rantai pasok (Nyamasage dan Biraori, 2015).

\section{Analisis Klasifikasi ABC}

Metode ABC dimana kegiatannya berorientasi pada aktivitas terkait biaya penugasan serta berorientasi pada proses juga dapat diimplementasikan untuk kualitas biaya, namun pengimplementasiaannya cenderung terbatas (Vaxevanidis et al. 2009). Analisis $\mathrm{ABC}$ menggunakan software $\mathrm{POM}-\mathrm{QM}$ dengan memasukkan komponen harga bahan baku per unit dan jumlah permintaan bahan baku yang digunakan selama satu periode. Bahan baku yang digunakan perusahaan saat ini diklasifikasikan dengan metode $\mathrm{ABC}$ dihasilkan bahan baku yang masuk ke dalam kelas A untuk tahun 2016 (Tabel 1) terdapat 6 bahan baku jenis Timber, 4 bahan baku jenis MDF, 1 bahan baku jenis Veneer, dan 4 bahan baku jenis PB. Sedangkan untuk data tahun 2017 (Tabel 2) yang masuk ke kelas A, terdapat 6 bahan baku jenis Timber, 5 bahan baku jenis MDF, 1 bahan baku jenis Veneer, dan 5 bahan baku jenis PB. Bahan baku yang masuk ke kelas A merupakan bahan baku yang memiliki persentase nilai pemakaian yang cukup besar dari total nilai pemakaian seluruh bahan baku untuk setiap jenisnya.

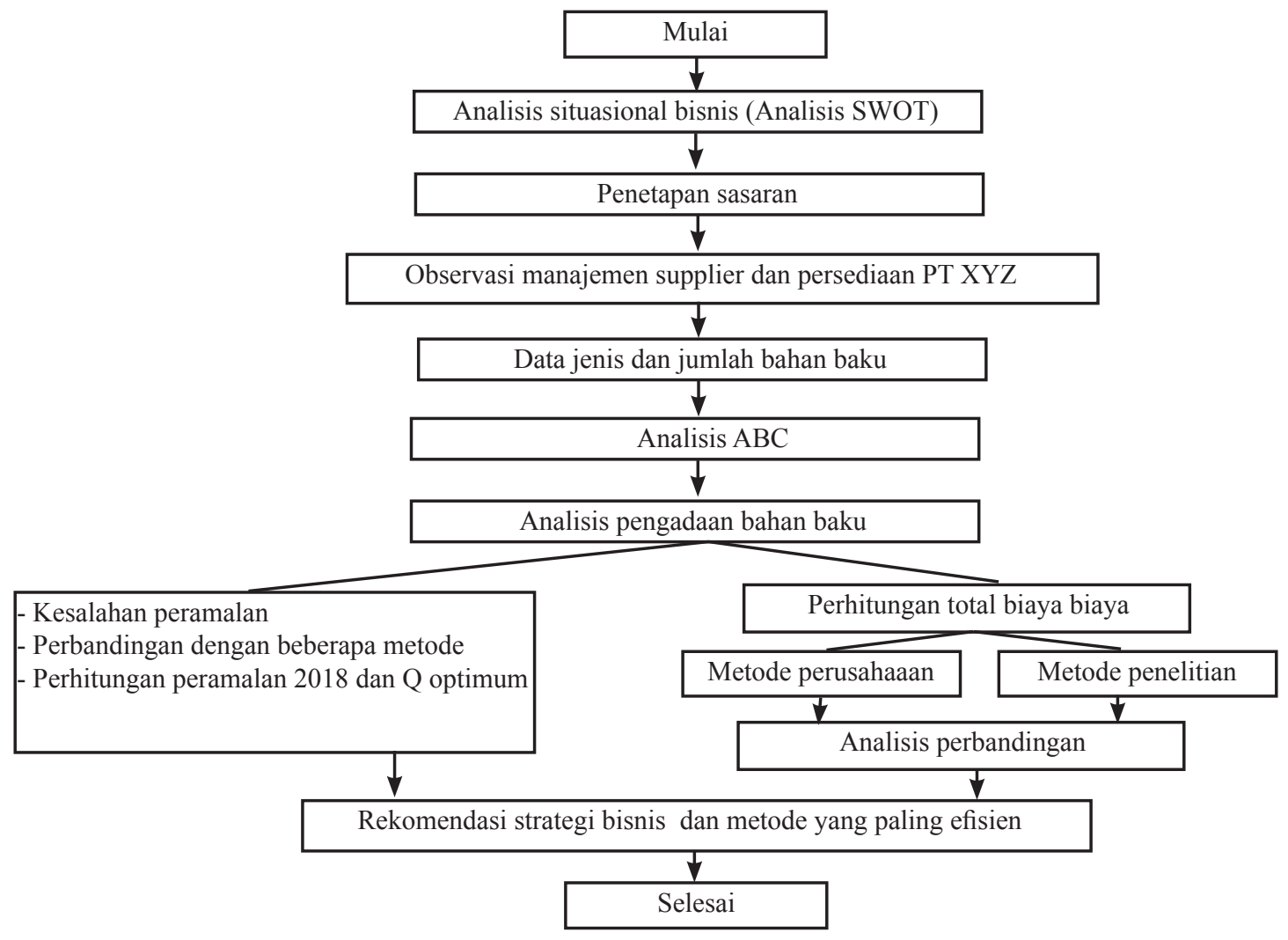

Gambar 1. Kerangka pemikiran penelitian 


\begin{tabular}{|c|c|c|}
\hline & $\begin{array}{l}\text { Kekuatan (strenght) } \\
\text { - Modal yang besar (S1) } \\
\text { - Citra yang cukup baik (S2) } \\
\text { - Memiliki sertifikat SVLK, FSC, dan } \\
\text { Komo (S3) } \\
\text { - Flexible dan lean manufacturing (S4) } \\
\text { - Kontinuitas produksi (S5) } \\
\text { - Quality control (S6) }\end{array}$ & $\begin{array}{l}\text { Kelemahan (weakness) } \\
\text { - Finishing produk masih dilakukan } \\
\text { subkontrak (W1) }\end{array}$ \\
\hline $\begin{array}{l}\quad \text { Peluang (opportunity) } \\
\text { - } \text { Konsumen yang loyal (O1) } \\
\text { - Perhatian terhadap lingkungan } \\
\text { (produk ramah lingkungan) (O2) } \\
\text { - Potensi pasar yang cukup besar (O3) } \\
\text { - Perkembangan teknologi produksi } \\
\quad(\mathrm{O} 4)\end{array}$ & $\begin{array}{l}\text { Strategi SO } \\
\text { - Meningkatkan pangsa pasar (S1, S2, } \\
\text { S3, S4, O1, O2, O3) } \\
\text { - Menambah kapasitas produksi (S1, } \\
\text { S2, S3, S4, S5, S6, O1, O2, O3, O4) }\end{array}$ & \begin{tabular}{l}
\multicolumn{1}{c}{ Strategi WO } \\
- Melakukan integrasi kedepan (W1, \\
O1, O2, O3, O4)
\end{tabular} \\
\hline $\begin{array}{l}\quad \text { Ancaman (Threat) } \\
\text { - Harga bahan baku yang meningkat } \\
\text { (T1) } \\
\text { - UMK yang meningkat (T2) } \\
\text { - Ketersediaan bahan baku yang } \\
\text { terbatas (T3) } \\
\text { - Harga jual yang menurun (sulit } \\
\text { untuk dinaikkan terkait persaingan) } \\
\text { (T4) }\end{array}$ & $\begin{array}{l}\text { Strategi ST } \\
\text { - Melakukan inovasi terkait bahan baku } \\
\text { (S1, S2, S3, S4, S5, T1, T3, T4) } \\
\text { - Meningkatkan teknologi produksi } \\
\text { (S1, S2, S4, S5, T2, T4) } \\
\text { - Meningkatkan efisiensi dan efektivitas } \\
\text { manajemen persediaan (S4, S5, S6, } \\
\text { T1, T2, T3, T4) }\end{array}$ & $\begin{array}{l}\text { Strategi WT } \\
\text { - Meningkatkan RnD (W1, T1, T2, } \\
\text { T3, T4) }\end{array}$ \\
\hline
\end{tabular}

Gambar 2. Matriks SWOT

Tabel 1. Bahan baku kelas A data tahun 2016 periode Januari-Desember

\begin{tabular}{|c|c|c|c|c|c|}
\hline & Jenis BB & Pemakaian (kubik) & Persentase (\%) & Persentase kumulatif & Kelas \\
\hline Timber & KD Pine 38 & 2680 & 16,69 & 16,69 & $\mathrm{~A}$ \\
\hline Timber & RST AD MERANTI 45MM & 2608 & 16,24 & 32,94 & A \\
\hline Timber & FJCL PINE CORE & 2306 & 14,36 & 47,3 & A \\
\hline Timber & MINDI & 2138 & 13,32 & 60,62 & A \\
\hline Timber & KD PINE 33 & 1785 & 11,12 & 71,73 & A \\
\hline Timber & SUNGKAI & 1167 & 7,27 & 79 & A \\
\hline MDF & MDF $6 \mathrm{~mm}$ FSC & 819 & 20,49 & 20,49 & A \\
\hline MDF & MDF 12mm CARB P2 FSC & 792 & 19,81 & 40,3 & A \\
\hline MDF & MDF 35mm E1 FSC & 778 & 19,46 & 59,75 & A \\
\hline MDF & HDF $2.5 \mathrm{~mm}$ FSC & 629 & 15,73 & 75,49 & A \\
\hline Veneer & W/O VENEER 0.6 & 582075 & 86,02 & 86,02 & A \\
\hline PB & PB 36MM E1 & 2073 & 31,4 & 31,4 & A \\
\hline PB & PB 32MM E1 & 1624 & 24,6 & 56 & A \\
\hline PB & PB 36MM FSC & 701 & 10,62 & 66,62 & A \\
\hline PB & PB 16MM E1 & 643 & 9,74 & 76,36 & A \\
\hline
\end{tabular}


Tabel 2. Bahan baku kelas A untuk tahun 2017 periode Januari-Agustus

\begin{tabular}{|c|c|c|c|c|c|}
\hline & Jenis BB & Pemakaian (kubik) & Persentase (\%) & Persentase kumulatif & Kelas \\
\hline Timber & FJCL Pine Core & 10824 & 19,18 & 19,18 & A \\
\hline Timber & Mindi & 8696 & 15,41 & 34,59 & A \\
\hline Timber & RST ADIKD Merbau & 7301 & 12,94 & 47,52 & A \\
\hline Timber & KD Pine 38 & 6011 & 10,65 & 58,17 & A \\
\hline Timber & RST AD ALBASIA 50/36MM & 5679 & 10,06 & 68,24 & A \\
\hline Timber & KD Pine 33 & 5158 & 9,14 & 77,38 & A \\
\hline MDF & MDF 6MM FSC & 3164 & 23,43 & 23,43 & A \\
\hline MDF & MDF 35MM E1 FSC & 2867 & 21,23 & 44,67 & A \\
\hline MDF & MDF 12MM CARB P2 FSC & 1832 & 13,57 & 58,24 & A \\
\hline MDF & MDF 15MM FSC & 1700 & 12,59 & 70,83 & A \\
\hline MDF & HDF 2.5 MM FSC & 1438 & 10,65 & 81,48 & A \\
\hline Veneer & W/O Veneer 1.2 & 154318 & 98,61 & 98,61 & A \\
\hline PB & PB 32MM E1 & 4604 & 27,1 & 27,1 & A \\
\hline PB & PB 36MM E1 & 4266 & 25,11 & 52,22 & A \\
\hline PB & PB 16MM E1 & 1933 & 11,38 & 63,6 & A \\
\hline PB & PB 32MM CARB P2 & 1700 & 10,01 & 73,61 & A \\
\hline PB & PB 36MM FSC & 1497 & 8,81 & 82,42 & A \\
\hline
\end{tabular}

\section{Kesalahan Peramalan}

Mengurangilead-timepadapasokan, produksi, distribusi dan konsumsi memberikan kesempatan bagi perusahaan untuk meningkatkan hal-hal tersebut dari ekspektasi minimum konsumen (Tersine dan Hummingbird, 1995). Peramalan yang dilakukan oleh perusahaan dihitung kesalahannya dan dibandingkan dengan metode lain. Hasil dengan kesalahan terkecil merupakan metode yang lebih tepat untuk digunakan. Kesalahan yang dihitung, yakni nilai Mean Absolute Deviation (MAD), MSE, dan MAPE dari masing-masing metode. Metode yang digunakan, yakni time series (linier dan kuadratik), moving average, dan double exponensial smoothing. Perbandingan kesalahan peramalan dilakukan dengan menghitung tingkat kesalahan peramalan perusahaan. Kemudian dengan data yang sama, dihitung tingkat kesalahan dengan metode linier, kuadratik, MA, dan double exponensial smoothing. Dengan menggunakan Minitab14 dihasilkan nilai MAD, MSE, dan MAPE yang dijadikan untuk membandingkan antar metode. Nilai MAD yang terkecil dijadikan sebagai acuan untuk menentukan metode terbaik (Tabel 3).

Data tahun 2016 sebagian besar metode yang digunakan perusahaan menunjukkan tingkat kesalahan yang lebih rendah, yakni untuk bahan baku Sungkai, W/O veneer $0,6, \mathrm{MDF} 35 \mathrm{~mm}$ E1 FSC, PB 36mm E1, PB $36 \mathrm{~mm}$ FSC, dan PB 32mm Carb P2. Artinya, ketepatan peramalan yang dilakukan perusahaan sudah cukup baik untuk jenis bahan baku tersebut. Beberapa jenis bahan baku lainnya masih kurang tepat. Sedangkan untuk tahun 2017, hanya bahan baku jenis MDF 35mm E1 FSC yang memiliki nilai kesalahan yang terendah dibanding metode pembanding lainnya. Itu artinya metode yang digunakan perusahaan sudah cukup baik. Akan tetapi, untuk jenis bahan baku lainnya, metode perusahaan masih memiliki tingkat kesalahan yang cukup tinggi. Tingginya tingkat kesalahan dipengaruhi peramalan sebelumnya yang berdampak terhadap permintaan aktual dan kemudian digunakan untuk data peramalan tahun berikutnya. Karena kesalahan dihitung dari rata-rata kesalahan absolut, dapat diketahui besar kecilnya peramalan berpengaruh besar terhadap tingkat kesalahan.

\section{Perkiraan Jumlah Optimum dengan Metode EOQ berdasarkan Metode Peramalan Terbaik}

Berdasarkan metode yang terbaik, hanya satu bahan baku, yakni MDF 35mm E1 FSC yang memiliki tingkat kesalahan yang lebih kecil dengan menggunakan metode perusahaan sehingga tidak dilakukan penghitungan untuk peramalan berikutnya. Selain itu bahan baku jenis PB 32mm CARB P2 memiliki hasil yang negatif dikarenakan fungsi peramalan dari metode terpilih kuadratik juga bernilai negatif. Sehingga ketika dilakukan perhitungan peramalan hasil yang ditunjukkan negatif yang membuat hasil penghitungan $\mathrm{Q}$ optimum juga negatif. Selanjutnya, 
dari hasil peramalan dihitung berapa jumlah optimum atau Q optimum dengan menggunakan metode EOQ. Jumlah optimum (Q) merupakan jumlah minimal yang baik untuk dipesan dalam pemenuhan bahan baku setiap minggunya (Tabel 4).

\section{Analisis Sediaan Menggunakan Metode EOQ}

Pengadaan bahan baku kepada pemasok dilakukan berdasarkan sisa bahan baku minimal di perusahaan dan rencana pemakaian dilakukan sesuai kesepakatan antara perusahaan dan tenaga kerja ahli, sehingga perusahaan dapat menentukan kebutuhan bahan baku untuk proses produksi (Supit dan Jan, 2015). Hasil jumlah optimum berdasarkan data permintaan perusahaan yang dapat digunakan dalam pemesanan bahan baku jika menggunakan metode EOQ. Berdasarkan jumlah yang optimal dapat diketahui juga berapa kali pemesanan yang optimal dengan cara membagi penggunaan (D) dengan $Q^{*}$ optimal. Selanjutnya, jumlah optimum metode EOQ ini, dijadikan sebagai bahan baku yang datang atau yang dipesan setiap minggunya. Hal ini dilakukan untuk melihat biaya yang dikerluarkan perusahaan jika menggunakan metode EOQ untuk satu periode. Sedangkan metode perusahaan tetap sesuai jumlah pesanan yang dilakukan perusahaan. Sehingga dapat diketahui biaya yang efisien untuk setiap bahan baku dalam setiap periode. Tahun 2017 dapat kita lihat pada Tabel 5.

Tabel 5 menunjukkan Qoptimum dan jumlahpemesanan yang dapat digunakan dengan menggunakan metode EOQ. Perhitungan total biaya metode EOQ dilakukan untuk melihat perbandingan biaya yang dikeluarkan perusahaan dalam satu periode dengan metode yang dilakukan perusahaan selama ini. Total biaya yang dihasilkan dengan metode EOQ secara keseluruhan lebih tinggi dibandingkan dengan metode perusahaan. Artinya, metode yang dilakukan perusahaan selama ini sudah efisien karena total biaya yang dikeluarkan untuk satu periode lebih rendah.

Tabel 3 Metode peramalan dengan kesalahan terkecil

\begin{tabular}{|c|c|c|c|}
\hline & \multirow{2}{*}{ Jenis bahan baku } & \multicolumn{2}{|c|}{ Metode dengan kesalahan terkecil } \\
\hline & & 2016 & 2017 \\
\hline \multirow[t]{8}{*}{ Timber } & KD PINE 38 & kuadratik & linear \\
\hline & RST AD MERANTI 45MM & kuadratik & - \\
\hline & FJCL PINE CORE & kuadratik & kuadratik \\
\hline & MINDI & kuadratik & kuadratik \\
\hline & KD PINE 33 & kuadratik & kuadratik \\
\hline & SUNGKAI & metode perusahaan & - \\
\hline & RST AD/KD MERBAU & & kuadratik \\
\hline & RST AD ALBASIA 50/36MM & & kuadratik \\
\hline \multirow[t]{2}{*}{ Veneer } & W/O VENEER 0.6 & metode perusahaan & - \\
\hline & W/O Veneer 1.2 & - & linear \\
\hline \multirow[t]{5}{*}{ MDF } & MDF 6mm FSC & kuadratik & kuadratik \\
\hline & MDF $12 \mathrm{~mm}$ CARB P2 FSC & kuadratik & kuadratik \\
\hline & MDF 35mm E1 FSC & metode perusahaan & metode perusahaan \\
\hline & HDF $2.5 \mathrm{~mm}$ FSC & linear & linear \\
\hline & MDF 15MM FSC & - & kuadratik \\
\hline \multirow[t]{5}{*}{ PB } & PB 36MM E1 & metode perusahaan & MA \\
\hline & PB 32MM E1 & kuadratik & kuadratik \\
\hline & PB 36MM FSC & metode perusahaan & MA \\
\hline & PB 16MM E1 & metode perusahaan & kuadratik \\
\hline & PB 32MM CARB P2 & - & kuadratik \\
\hline
\end{tabular}


Tabel 4. Jumlah optimum dengan metode EOQ berdasarkan metode peramalan yang terbaik

\begin{tabular}{llc}
\hline & Jenis bahan baku & Q optimum \\
\hline Timber & FJCL Pine core & 32 \\
& Mindi & 31 \\
& RST AD/KD MERBAU & 14 \\
& KD Pine 38 & 36 \\
& RST AD ALBASIA 50/36MM & 50 \\
& KD Pine 33 & 86 \\
Veneer & W/O Veneer 1.3 & 3980 \\
MDF & MDF 6MM FSC & 29 \\
& MDF 12MM CARB P2 FSC & 69 \\
& MDF 15MM FSC & 31 \\
PB & HDF 2.5MM FSC & 22 \\
& PB 32MM E1 & 60 \\
& PB 36MM E1 & 84 \\
& PB 16MM E1 & 10 \\
PB 32MM CARB P2 & 42 \\
& PB 36MM FSC & 13 \\
\hline
\end{tabular}

Tabel 5. Perhitungan jumlah pesanan optimal metode EOQ data tahun 2017

\begin{tabular}{llccccc}
\hline & Jenis bahan baku & Penggunaan & EOQ $\left(Q^{*}\right)$ & $\begin{array}{c}\text { Jumlah } \\
\text { pesanan metode } \\
\text { (D) (kubik) }\end{array}$ & & \multicolumn{2}{c}{ Total biaya (\$/thn) } \\
\cline { 6 - 7 } & EOQ (kali) & Metode EOQ & $\begin{array}{c}\text { Metode } \\
\text { perusahaan }\end{array}$ \\
\hline Timber & FJCL PINE CORE & 1.460 & 33 & 44 & 1.753 & 1.719 \\
& MINDI & 974 & 27 & 36 & 1.432 & 1.405 \\
& RST AD/KD MERBAU & 499 & 19 & 26 & 1.025 & 754 \\
& KD Pine 38 & 1.651 & 35 & 47 & 1.865 & 2.258 \\
& RST AD ALBASIA 50/36MM & 585 & 21 & 28 & 1.110 & 727 \\
& KD Pine 33 & 1.535 & 34 & 45 & 1.798 & 2.023 \\
Veneer & W/O Veneer 1.2 & 33.918 & 3.483 & 10 & 390 & 69 \\
& MDF 6MM FSC & 582 & 33 & 18 & 705 & 608 \\
& MDF 35MM E1 FSC & 617 & 34 & 18 & 727 & 687 \\
& MDF 12MM CARB P2 FSC & 629 & 34 & 18 & 733 & 597 \\
& MDF 15MM FSC & 296 & 24 & 13 & 503 & 309 \\
PB & HDF 2.5 MM FSC & 452 & 25 & 18 & 720 & 467 \\
& PB 32MM E1 & 1.066 & 56 & 19 & 768 & 414 \\
& PB 36MM E1 & 1.539 & 67 & 23 & 922 & 571 \\
\hline
\end{tabular}

Perbandingan total biaya juga dilakukan untuk data tahun 2016 (Tabel 6) menggunakan metode EOQ dan metodeperusahaan. Hasilpada tabeldiatas menunjukkan total biaya menggunakan metode EOQ juga masih lebih tinggi dibandingkan dengan metode perusahaan. Hanya terdapat empat jenis bahan baku yang memiliki total biaya lebih tinggi dengan menggunakan metode perusahaan yakni KD Pine 38, RST AD Meranti 45mm, FJCL Pine Core, dan Mindi. Besarnya biaya keempat biaya bahan baku ini dapat dipengaruhi jumlah pemesanan dan pesanan yang dilakukan. Karena jumlah pemesanan metode perusahaan tidak mengikuti jumlah pemesanan yang baku seperti metode EOQ. 
Tabel 6. Perhitungan jumlah pesanan optimal metode EOQ data tahun 2016

\begin{tabular}{|c|c|c|c|c|c|c|}
\hline & \multirow[b]{2}{*}{ Jenis bahan baku } & \multirow[b]{2}{*}{$\begin{array}{l}\text { Penggunaan } \\
\text { (D) (kubik) }\end{array}$} & \multirow{2}{*}{$\begin{array}{c}\text { EOQ }\left(Q^{*}\right) \\
\text { (kubik) }\end{array}$} & \multirow{2}{*}{$\begin{array}{c}\text { Jumlah } \\
\text { pesanan metode } \\
\text { EOQ (kali) }\end{array}$} & \multicolumn{2}{|c|}{ Total biaya $(\$ /$ thn $)$} \\
\hline & & & & & Metode EOQ & $\begin{array}{c}\text { Metode } \\
\text { perusahaan }\end{array}$ \\
\hline \multirow[t]{6}{*}{ Timber } & KD PINE 38 & 2.680 & 45 & 59 & 2.375 & 2.826 \\
\hline & RST AD MERANTI 45MM & 2.608 & 45 & 59 & 2.343 & 2.603 \\
\hline & FJCL PINE CORE & 2.306 & 42 & 55 & 2.204 & 2.504 \\
\hline & MINDI & 2.138 & 40 & 53 & 2.122 & 3.026 \\
\hline & KD PINE 33 & 1.785 & 37 & 48 & 1.939 & 1.287 \\
\hline & SUNGKAI & 1.167 & 30 & 39 & 1.567 & 1.480 \\
\hline Veneer & W/O VENEER 0.6 & 582.075 & 14.427 & 40 & 1.614 & 1.100 \\
\hline \multirow[t]{4}{*}{ MDF } & MDF 6mm FSC & 819 & 39 & 21 & 837 & 613 \\
\hline & MDF $12 \mathrm{~mm}$ CARB P2 FSC & 792 & 38 & 21 & 823 & 587 \\
\hline & MDF 35mm E1 FSC & 778 & 38 & 20 & 816 & 631 \\
\hline & $\mathrm{HDF} 2.5 \mathrm{~mm}$ FSC & 629 & 30 & 21 & 848 & 614 \\
\hline \multirow[t]{4}{*}{ PB } & PB 36MM E1 & 2.073 & 77 & 27 & 1.070 & 881 \\
\hline & PB 32MM E1 & 1.624 & 69 & 24 & 947 & 727 \\
\hline & PB 36MM FSC & 701 & 39 & 18 & 725 & 471 \\
\hline & PB 16MM E1 & 643 & 39 & 17 & 667 & 313 \\
\hline
\end{tabular}

\section{Analisis Sediaan Pengaman (Safety Stock)}

Berdasarkan data produksi perusahaan, menunjukkan tingkat penggunaan bahan baku sangat fluktuatif. Diperlukan tingkat ketersediaan bahan baku yang tepat untuk mengamankan produksi agar tetap berjalan dengan baik. Tabel 7 menunjukkan hasil perhitungan stok pengaman yang dapat digunakan perusahaan untuk tahun 2016 dan 2017. Sediaan pengaman sebagai persediaan yang dilakukan utnuk mencegah kehabisan persediaan dan keterlambatan pemesanan. Sediaan pengaman melindungi dari penyimpangan tanggal pengiriman, varian kebutuhan, varian kuantitas pengiriman dan varian persediaan (Radasanu, 2016).

Persedian pengaman merupakan perhitungan dari standar deviasi penggunaan dalam satu periode dikalikan dengan sebaran deviasi 95\% (1,65). Service level 99,9\% dapat menghasilkan jumlah persediaan cadangan yang jauh lebih kecil dibanding persediaan cadangan yang dilakukan perusahaan (Purnamasari, 2011). Persedian pengaman digunakan ketika kondisi tertentu seperti permintaan meningkat dan keterlambatan pengiriman bahan baku. Akan tetapi, perusahaan harus menjaga stok pengaman dalam jumlah sesuai dengan hasil perhitungan diatas agar dapat mencegah terjadinya kehabisan stok (stockout). Demikian juga yang dikemukakan Sharan (2016) dengan tingkat persediaan tujuh unit merupakan tingkat persediaan dengan total biaya terendah. Oleh karena itu, tingkatan persediaan pengaman tidak hanya berpengaruh terhadap proses produksi juga terhadap biaya yang dikeluarkan.

\section{Implikasi Manajerial}

Pengendalian bahan baku sudah dilakukan dengan sangat baik oleh perusahaan, penulis memberikan rekomendasi hal-hal berikut untuk perbaikan dalam pengendalian bahan baku, yaitu terkait hubungan dengan pemasok, perusahaan dapat melakukan kerja sama yang berkaitan dengan salah satu divisi dalam agar menghasilkan bahan baku yang lebih baik salah satunya untuk mengurangi bahan baku yang rusak. Selanjutnya, perusahaan dapat melakukan pengklasifikasian bahan baku agar dapat mengetahui mana bahan baku yang memiliki nilai pakai yang besar sehingga mempengaruhi biaya yang dikeluarkan oleh perusahaan. Di samping itu, perlu dilakukan peramalan yang lebih baik untuk masing-masing bahan baku karena sangat mempengaruhi terhadap penggunaan bahan baku dan biaya yang dikeluarkan. Tingginya total biaya juga dipengaruhi bahan baku yang berlebih sebagai dampak dari kesalahan peramalan. 
Tabel 7. Stok pengaman (safety stock) tahun 2016 dan 2017

\begin{tabular}{llcc}
\hline & \multirow{2}{*}{ Jenis bahan baku } & \multicolumn{2}{c}{ Q optimum } \\
\cline { 2 - 3 } Timber & KD PINE 38 & Sedian pengaman (kubik) & Sediaan pengaman (kubik) \\
& RST AD MERANTI 45MM & 111 & 112 \\
& FJCL PINE CORE & 118 & - \\
& MINDI & 122 & 139 \\
& KD PINE 33 & 85 & 141 \\
& SUNGKAI & 94 & - \\
& RST AD/KD MERBAU & - & 57 \\
Veneer & RST AD ALBASIA 50/36MM & - & 97 \\
& W/O VENEER 0.6 & 25.342 & - \\
MDF & W/O Veneer 1.2 & - & 3.783 \\
& MDF 6mm FSC & 42 & 51 \\
& MDF 12mm CARB P2 FSC & 39 & 45 \\
& MDF 35mm E1 FSC & 37 & 61 \\
PB & HDF 2.5mm FSC & 21 & 29 \\
& MDF 15MM FSC & - & 31 \\
& PB 36MM E1 & 122 & 119 \\
& PB 32MM E1 & 88 & 97 \\
& PB 36MM FSC & 77 & 80 \\
& PB 16MM E1 & 50 & 45 \\
& PB 32MM CARB P2 & - & 70 \\
\hline
\end{tabular}

\section{KESIMPULAN DAN SARAN}

\section{Kesimpulan}

Strategi fungsional yang dapat dilakukan perusahaan yaitu meningkatkan efektivitas dan efisiensi pengadaan bahan baku untuk menghadapi segala ancaman dan kelemahan yang dihadapi. Perusahaan memiliki kriteria yang harus dipenuhi pemasok untuk memenuhi kebutuhan perusahan. Kriteria yang harus dipenuhi diantaranya harga, lead time, tempo pembayaran, kualitas, dan legalitas perusahaan. Strategi yang dilakukan perusahaan, yakni dengan bekerja dengan beberapa pemasok terlihat dari pemesanan untuk masing-masing bahan baku dapat bersumber lebih dari satu pemasok. Selanjutnya, untuk hubungan yang ada antara perusahaan dan pemasok, perusahaan memiliki hubungan partnership tipe pertama. Dimana perusahaan dan pemasok berkoordinasi terbatas dalam kegiatan dan perencanaan dan waktu jengka pendek.

Bahan baku yang digunakan perusahaan saat ini diklasifikasikan dengan metode $\mathrm{ABC}$ dihasilkan bahan baku yang masuk ke dalam kelas A untuk tahun 2016 terdapat enam bahan baku jenis Timber, empat bahan baku jenis MDF, satu bahan baku jenis Veneer, dan empat bahan baku jenis PB. Data tahun 2017 yang masuk ke kelas A, terdapat enam bahan baku jenis Timber, lima bahan baku jenis MDF, satu bahan baku jenis Veneer, dan lima bahan baku jenis PB. Bahan baku yang masuk ke kelas A merupakan bahan baku yang memiliki persentase nilai pemakaian yang cukup besar dari total nilai pemakaian seluruh bahan baku untuk setiap jenisnya. Perhitungan kesalahan peramalan berdasarkan nilai MAD dengan membandingkan kesalahan peramalan perusahaan dengan beberapa metode (metode kuadratik, linear, moving average, dan double exponential smoothing) terdapat empat jenis bahan baku untuk tahun 2016 yang memiliki nilai kesalahan lebih rendah (menggunakan metode perusahaan) dibanding metode pembanding. Tahun 2017 hanya satu jenis bahan baku yang memiliki nilai kesalahanlebihkecil(menggunakanmetodeperusahaan) dibanding metode pembanding lainnya. Berdasarkan metode terbaik, kemudian dihitung peramalan untuk tahun 2018 dan jumlah Q optimum yang dapat menjadi acuan. Hasil perbandingan perhitungan total biaya dengan menggunakan metode perusahaan dan metode EOQ. Data tahun 2017 terdapat dua bahan baku yaitu 
KD Pine 38 dan KD Pine 33 yang memiliki total biaya yang lebih tinggi menggunakan metode perusahaan sedangkan yang lainnya lebih rendah. Data tahun 2016 terdapat empat jenis bahan baku yakni KD Pine 38, RST AD Meranti 45mm, FJCL Pine Core, dan Mindi yang memiliki total biaya lebih tinggi dibandingkan dengan metode EOQ. Secara keseluruhan total biaya metode perusahaan jauh lebih rendah dibanding dengan menggunakan metode EOQ. Penggunaan safety stock memiliki peran yang penting untuk dapat mencegah adanya kehabisan bahan baku. Dengan melihat efisiensi total biaya yang dihasilkan selama ini, menunjukkan bahwa penggunaan safety stock belum begitu diperhatikan oleh perusahaan karena masih terjadi kehabisan bahan baku. Hal ini menunjukkan bahwa secara metode yang digunakan oleh perusahaan selama ini belum cukup efisien melihat perbandingan total biaya yang dihasilkan.

\section{Saran}

Perlu adanya penelitian lanjutan terhadap perhitungan peramalan yang lebih tepat untuk masing-masing bahan baku. Selain itu, penggunaan metode pembanding yang lebih sesuai dengan kondisi pengadaan perusahaan untuk menghitung total biaya.

\section{DAFTAR PUSTAKA}

Ananta Z, Hubeis M, Palupi NS. 2007. Penerapan manajemen strategik pada industri pengolahan kayu perusahaan XYZ di kelurahan Bojong Kulur, Gunung Putri, Bogor. Jurnal MPI 2(1):24-35.

Hayuningtyas RY. 2017. Peramalan persediaan barang menggunakan metode weighted moving average dan metode double exponential smoothing. Jurnal PILAR Nusa Mandiri 13(2):217-222.

Nyamasege OJ, Biraori OE. 2015. Effect of supplier relationship management on the effectiveness of supply chain management in the Kenya public sector. International Journal of Managing Value and Supply Chains (IJMVSC) 6(1):25-32. https:// doi.org/10.5121/ijmvsc.2015.6103.

Ordoobadi SM, Wang S. 2011. Amultiple perpectives approach to supplier selection. Industrial Management \& Data System 111(4):629-648. https://doi.org/10.1108/02635571111133588.

Prihatna IH. 2007. Kajian rantai pasok (supply chain) bahan pada PT. Fajar Taurus [tesis]. Bogor:
Institut Pertanian Bogor.

Purnamasari H. 2011. Peningkatan efisiensi manajemen rantai pasok melalui pengendalian persediaan filler dan bahan kemasan roti manis di PT. Nippon Indosari Corpindo [tesis]. Bogor: Institut Pertanian Bogor.

Radasanu AC. 2016. Inventory management, service level and safety stock. Journal of Public Administration, Finance and Law 9:145-153.

Rajeev N. 2008. Inventory management in small and medium enterprises. Management Research News 31(9):659-669. https://doi. org/10.1108/01409170810898554.

Sarkar A, Mohapatra PKJ. 2006. Evaluatioan of supplier capability and performance: a method for supply base reduction. Journal of Purchasing \& Supply Management 12:148-163. https://doi. org/10.1016/j.pursup.2006.08.003.

Sharan U. 2016. Analysis of safety stock. International Research Journal of Engineering and Technology 3(2):1603-1605.

Stock JR, Lambert DM. 2001. Strategic Logistics Management 4th ed. Singapore:The McGrawHill.

Supit T, Jan AH. 2015. Analisa persediaan bahan baku pada industri mebel di desa leilem. Jurnal EMBA 3(1):1230-1241.

Tarigan ZJH. 2009. Dukungan manajemen puncak terhadap strategic purchasing dalam berkomunikasi dan berkolaborasi dengan supplier untuk meningkatkan kinerja perusahaan. Jurnal Manajemen dan Kewirausahaan 11(2):126133.

Tersine RJ, Hummingbird EA. 1995. Lead-time reduction: the search for competitive advantage. International Journal of Operation \& Production Management 15(2):8-18. https://doi. org/10.1108/01443579510080382.

Thomas DJ, Griffin PM. 1996. Coordinated supply chain management. European Journal of Operational Research 94:1-15. https://doi.org/10.1016/03772217(96)00098-7.

Utama CA, Watequlis YS. 2016. Pengembangan si stok barang dengan peramalan menggunakan metode double exponential smoothing (studi kasus: PT. Tomah Jaya Elektrikal). Jurnal Informatika Polinema 2(4):147-153. https://doi. org/10.33795/jip.v2i4.74.

Vaxevanidis N M, Petropoulos G, Avakumovic J, Mourlas A. 2009. Cost of quality models and their implementation in manufacturing firms. 
International Journal for Quality research 3(1):27-36.

Verma R, Pullman ME. 1998. An analysis of the supplier selection process. Omega-International Journal of Management Science 26(6):739-750. https:// doi.org/10.1016/S0305-0483(98)00023-1.

Wheelen TL, Hunger JD. 2012. Concepts in Strategic Management and Business Policy. Amerika: Pearson Education, Inc.
Widiyarini. 2016. Penggunaan metode peramalan produksi kayu untuk penentuan total permintaan (konsumen). Journal SOSIO-E-KONS 8(1):5461.

Windria NH. 2001. Kajian perencanaan pengendalian persediaan bahan baku tuna Loin jenis yellowfin (Studi kasus pada PT. Boneccom, Jakarta) [tesis]. Bogor: Institut Pertanian Bogor. 